\title{
Enhancement of cranial nerves, conus medullaris, and nerve roots in POLG mitochondrial disease
}

Michael Bayat, MD, Yousef Yavarian, MD, Allan Bayat, MD, and Jakob Christensen, MD, PhD

Neurol Genet 2019;5:e360. doi:10.1212/NXG.0000000000000360

\author{
Correspondence \\ Dr. Bayat \\ bayat86@hotmail.com
}

A 20-year-old female patient was admitted to our department due to ptosis, double vision, and difficulty walking. The symptoms had evolved during the course of 2 months. She had never been very athletic and was described as always having been a "slow runner," but otherwise her previous history was unremarkable. There was no family history of neurologic disease. There were no preceding triggering factors such as infections, fever, or physical stress, and the patient did not take valproate. On examination, she had bilateral external ophthalmoplegia and ptosis, grade 4 proximal and distal paresis in the lower extremities, grade 4 distal paresis in the upper extremities, distal sensory loss (for all sensory modalities), and sensory ataxia. After several months, she started experiencing a very slow improvement, which is-at the present moment—still incomplete.

MRI showed enhancement of the oculomotor nerves, the conus medullaris, the adjacent leptomeninges, and the cauda equina nerves. In the course of $1 \frac{1 / 2}{2}$ years, 5 MRI scans of the brain and medulla were performed, and the findings were stationary and independent of the acute decline. The radiologic findings were present before a lumbar puncture was performed.

Electroneuronography showed signs of an axonal neuropathy mainly affecting the lower extremities. CSF examination revealed a mild pleocytosis ( 7 cells) [reference $<5$ cells/ $\left.\mathrm{mm}^{3}\right]$, elevated protein $(22 \mathrm{mg} / \mathrm{dL})[$ reference $20-50 \mathrm{mg} / \mathrm{dL})$, and elevated lactate $(3.3$ $\mathrm{mmol} / \mathrm{L}$ ) [reference $1.2-2.1 \mathrm{mmol} / \mathrm{L}$ ). Several repeat CSF examinations were performed and showed the same abnormalities. CSF was negative for viruses and bacteria including Borrelia burgdorferi, syphilis, and tuberculosis. CSF cytology and flow cytometry were performed on 3 consecutive samples and revealed no tumor cells. Blood samples showed normal thyroid and liver functions tests and were negative for HIV serology, hepatitis B and C serology, tuberculosis (QuantiFERON test), syphilis, monoclonal protein, antinuclear antibody, antineutrophil cytoplasmic antibodies, antiphospholipid antibodies, angiotensin-converting enzyme, paraneoplastic antibodies, aquaporin-4 antibodies, contactin-1 and neurofascin-155 antibodies, ganglioside antibodies (incl.GQ1B), and acetylcholine receptor antibodies. Serum lactate was not measured. PET CT showed no abnormalities.

The clinical phenotype was compatible with sensory ataxic neuropathy, dysarthria, and ophthalmoparesis. Genetic testing revealed that she was compound heterozygous for 2 pathogenic polymerase gamma 1 (POLG) variants (c.2243G $>C$ and c.2391G $>$ T) located on chromosome 15. Parental DNA testing showed that the POLG variants were in trans position and therefore responsible for the clinical phenotype. The POLG gene is essential for the function of the only DNA polymerase that is active in mitochondria and can replicate in mitochondrial DNA (figures 1 and 2).

From the Department of Neurology (M.B., J.C.), Aarhus University Hospital; Centre for Rare Diseases (M.B.), Department of Pediatrics, Aarhus University Hospital; Department of Radiology (Y.Y.), Aalborg University Hospital; and Danish Epilepsy Centre (A.B.), Dianalund, Denmark.

Go to Neurology.org/NG for full disclosures. Funding information is provided at the end of the article.

The Article Processing Charge was funded by Novo Nordisk Foundation NNF16OC0019126.

This is an open access article distributed under the terms of the Creative Commons Attribution-NonCommercial-NoDerivatives License 4.0 (CC BY-NC-ND), which permits downloading and sharing the work provided it is properly cited. The work cannot be changed in any way or used commercially without permission from the journal. 
Figure 1 Contrast-enhanced T1-weighted axial and coronal fat-saturated images showing bilateral smooth enhancement of the oculomotor nerves (arrows)

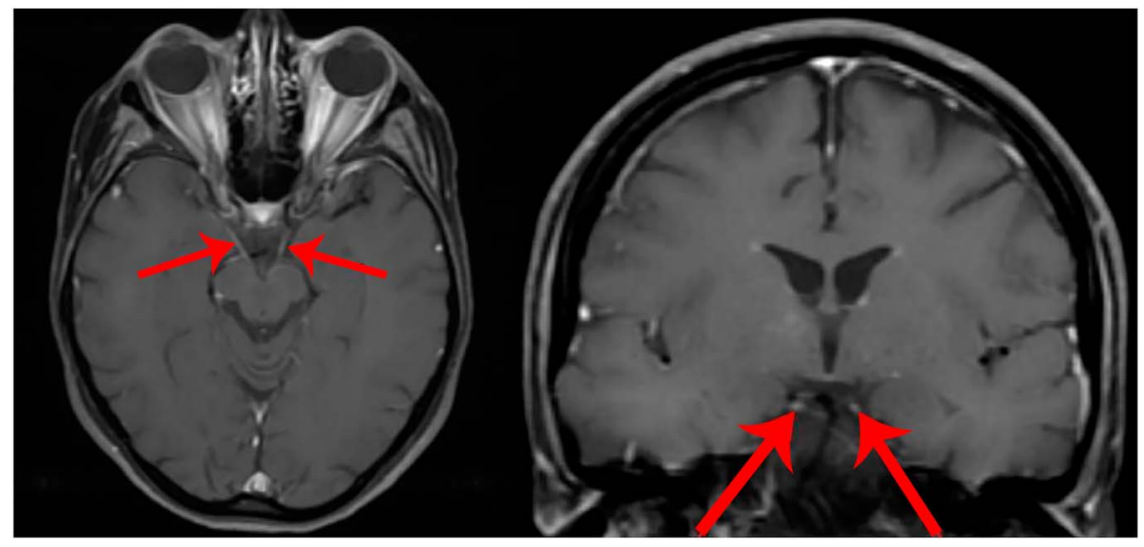

There has been only 1 previous report of abnormal nerve enhancement in mitochondrial disease. That report involved an infant patient with POLG variants whose MRI showed oculomotor nerve and cervical root enhancement. ${ }^{1}$ The pattern of enhancement in our patient (involving the cranial nerves, conus medullaris, and cauda equine nerve roots) is rare and usually not associated with mitochondrial disease. We believe that the patient has been thoroughly investigated and has been followed clinically for more than 1 year without emergence of symptoms compatible with a systemic condition such as an autoimmune or neoplastic disorder. Therefore, it is considered likely that the MRI findings are caused by the mitochondrial disorder, although a peripheral nerve or nerve root biopsy was not performed.

POLG-related disorder can be associated with MRI changes of the brain parenchyma. A review of 136 patients with
POLG-related epilepsy showed that stroke-like lesions were the most prevalent abnormalities (43\%), followed by thalamic (37\%), cerebellar (17\%), basal ganglia (14\%), and cerebral white matter (7\%) lesions. Generalized atrophy was also prevalent $(28 \%)$. No such lesions were found in our patient. ${ }^{2}$

The differential diagnoses for nerve root and conus medullaris enhancement are very broad and include infectious, autoimmune, and neoplastic disorders. ${ }^{3}$ Mitochondrial disease is a very rare cause of nerve enhancement. The reason for the enhancement is not known, and it is unclear whether it is a distinguishing property of POLG variants or whether the enhancement is to be found in other mitochondrial variants as well. Routine use of contrast in the radiologic evaluation of patients with neurologic manifestations of mitochondrial disease could help elucidate this.

Figure 2 Contrast-enhanced sagittal T1-weighted and axial fat-saturated images showing enhancement of the conus medullaris (A) and cauda equina nerve roots (B) (arrows)
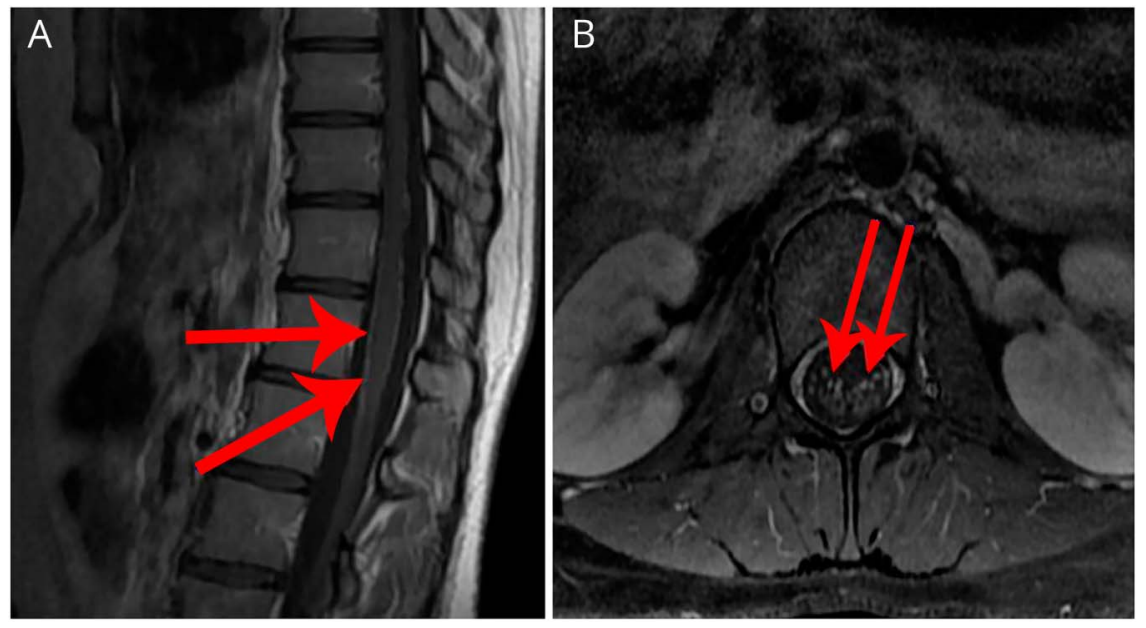
With this case, we wish to highlight that POLG-associated mitochondrial disorder should be included as a differential diagnosis in patients with enhancement of the cranial nerves, nerve roots, and the conus medullaris.

\section{Study funding}

J. Christensen and M. Bayat were supported by the Danish Epilepsy Association, Central Denmark Region, and Novo Nordisk Foundation (grant NNF16OC0019126).

\section{Disclosure}

J. Christensen reported receiving honoraria from serving on the scientific advisory boards of and giving lectures for $\mathrm{UCB}$ Nordic and Eisai $\mathrm{AB}$ and receiving travel funding from UCB Nordic. The other authors have no conflicts of interest. Go to Neurology.org/NG for full disclosures.

\section{Publication history}

Received by Neurology: Genetics April 12, 2019. Accepted in final form July 10, 2019.

\section{Appendix Authors}

\begin{tabular}{llll}
\hline Name & Location & Role & Contribution \\
\hline $\begin{array}{l}\text { Michael } \\
\text { Bayat, MD }\end{array}$ & $\begin{array}{l}\text { Aarhus } \\
\text { University } \\
\text { Hospital }\end{array}$ & Author & $\begin{array}{l}\text { Designed and } \\
\text { conceptualized the study } \\
\text { and drafted the manuscript }\end{array}$ \\
\hline $\begin{array}{l}\text { Yousef } \\
\text { Yavarian, } \\
\text { MD }\end{array}$ & $\begin{array}{l}\text { Aalborg } \\
\text { University } \\
\text { Hospital }\end{array}$ & Author & $\begin{array}{l}\text { Data collection and analysis } \\
\text { (radiology) }\end{array}$ \\
$\begin{array}{l}\text { Allan Bayat, } \\
\text { MD }\end{array}$ & $\begin{array}{l}\text { Danish } \\
\text { Epilepsy } \\
\text { Centre, } \\
\text { Dianalund }\end{array}$ & Author & $\begin{array}{l}\text { Drafting and revision of the } \\
\text { manuscript }\end{array}$ \\
$\begin{array}{llll}\text { Jakob } \\
\text { Christensen, } \\
\text { MD }\end{array}$ & $\begin{array}{l}\text { Aarhus } \\
\text { University } \\
\text { Hospital }\end{array}$ & Author & $\begin{array}{l}\text { Drafting and revision for } \\
\text { intellectual content }\end{array}$ \\
\hline
\end{tabular}

\section{References}

1. Horst DM, Ruess L, Rusin JA, Bartholomew DW. Cranial nerve and cervical root enhancement in an infant with polymerase gamma mutation mitochondrial disease. Pediatr Neurol 2014;51:734-736.

2. Anagnostou ME, Ng YS, Taylor RW, McFarland R. Epilepsy due to mutations in the mitochondrial polymerase gamma (POLG) gene:a clinical and molecular genetic review. Epilepsia 2016;57:1531-1545.

3. Georgy BA, Snow RD, Hesselink JR. MR imaging of spinal nerve roots: techniques, enhancement patterns, and imaging findings. AJR Am J Roentgenol 1996;166:173-179. 


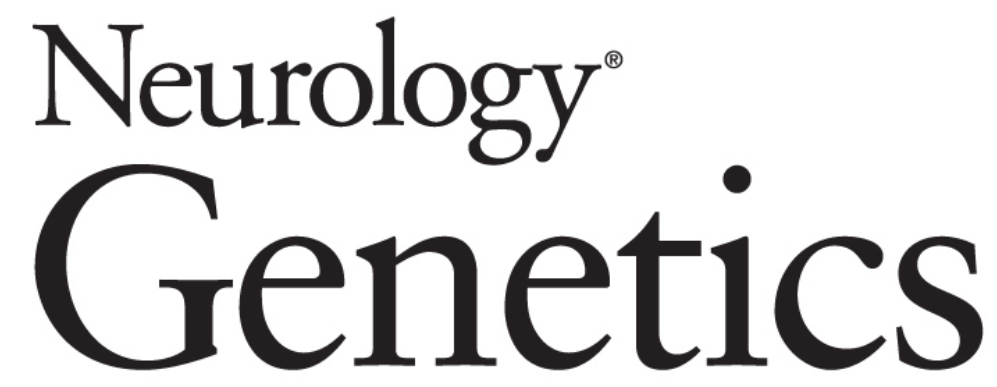

Enhancement of cranial nerves, conus medullaris, and nerve roots in POLG mitochondrial disease

Michael Bayat, Yousef Yavarian, Allan Bayat, et al. Neurol Genet 2019;5;

DOI 10.1212/NXG.0000000000000360

This information is current as of September 9, 2019

Neurol Genet is an official journal of the American Academy of Neurology. Published since April 2015, it is an open-access, online-only, continuous publication journal. Copyright Copyright @ 2019 The Author(s). Published by Wolters Kluwer Health, Inc. on behalf of the American Academy of Neurology.. All rights reserved. Online ISSN: 2376-7839.

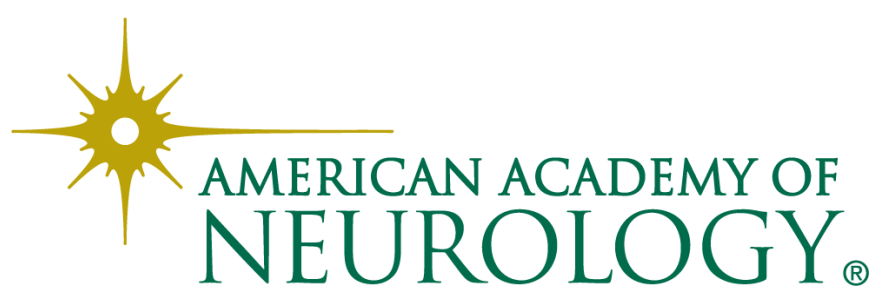




\section{Updated Information \& Services}

References

Subspecialty Collections

Permissions \& Licensing

Reprints including high resolution figures, can be found at:

http://ng.neurology.org/content/5/5/e360.full.html

This article cites 3 articles, 0 of which you can access for free at: http://ng.neurology.org/content/5/5/e360.full.html\#\#ref-list-1

This article, along with others on similar topics, appears in the following collection(s):

All Clinical Neurology

http://ng.neurology.org//cgi/collection/all_clinical_neurology

All Genetics

http://ng.neurology.org//cgi/collection/all_genetics

All Neuromuscular Disease

http://ng.neurology.org//cgi/collection/all_neuromuscular_disease Mitochondrial disorders

http://ng.neurology.org//cgi/collection/mitochondrial_disorders

MRI

http://ng.neurology.org//cgi/collection/mri

Information about reproducing this article in parts (figures,tables) or in its entirety can be found online at:

http://ng.neurology.org/misc/about.xhtml\#permissions

Information about ordering reprints can be found online:

http://ng.neurology.org/misc/addir.xhtml\#reprintsus

Neurol Genet is an official journal of the American Academy of Neurology. Published since April 2015, it is an open-access, online-only, continuous publication journal. Copyright Copyright $\odot 2019$ The Author(s). Published by Wolters Kluwer Health, Inc. on behalf of the American Academy of Neurology.. All rights reserved. Online ISSN: 2376-7839.

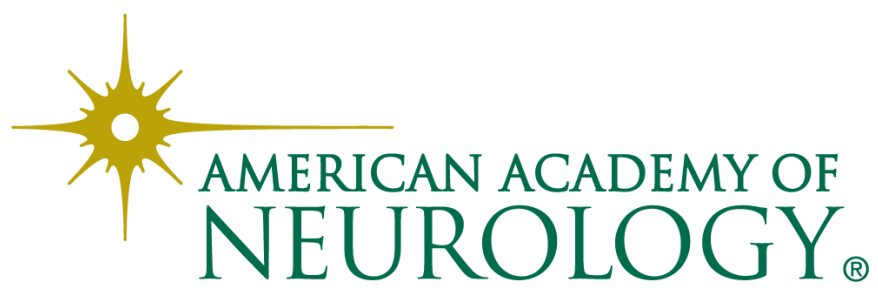

